\title{
System Dynamics Model for Improving Salt Quality to Achieve Self-Sufficiency of Industrial Salt
}

\author{
Gustin Ayu Cahyandini, Erma Suryani and Raulia Riski \\ Department of Information Systems, Institut Teknologi Sepuluh Nopember, Surabaya \\ e-mail: erma.suryani@gmail.com
}

\begin{abstract}
Salt is a very important commodity for human life. In addition to consumption, salt is also needed in several industries, including for the Chlor Alkali Plant (CAP) industries, pharmaceutical, and non-CAP industries such as petroleum, salting, and others. The demand for industrial salt in Indonesia continues to increase every year along with the growth and development of industries in Indonesia. However, the salt produced by Indonesian salt farmers is still low in quality and can only meet the needs of consumption salt because they only contain about $94 \%$ to $95 \% \mathrm{NaCl}$. Therefore, local salt is difficult to be absorbed by with salt-based products industry because its purity level does not meet the industrial standards. As a result, imports of industrial salt will increase because local salt cannot meet the industry needs. This study aims to build a conceptual model in order to improve the quality of salt in Indonesia in order to produce a good quality salt that meet the industrial salt standards and can be absorbed by the industrial sector in Indonesia with system dynamics approach. The results of this study are conceptual models regarding internal and external factors that influence the improvement of salt quality to meet the needs of industrial salt. The model can be used by the government and related parties in developing strategies and policies related to industrial salt cultivation. Further research can be done by developing several scenarios to predict future salt cultivation systems.
\end{abstract}

Keywords-Salt, Industrial Salt, Self-sufficiency, System Dynamics, Causal Loop Diagram.

\section{INTRODUCTION}

$\mathrm{I}_{\mathrm{b}}^{\mathrm{s}}$ NDONESIA has great marine potential to develop marinebased cultivation. One of them is salt cultivation. Salt is a very important commodity for human life. Salt is divided into 2 types, namely: (1) iodized salt or consumption salt, is salt used as raw material for the production of iodized consumption salt industry [1]. This type of salt is used for a variety of foods that have a minimum of $94.7 \% \mathrm{NaCl}$ and for marinating fish [2]; (2) Non-iodized salt or industrial salt is salt used as raw material for industries with salt-based products with levels of $\mathrm{NaCl}$ above $97 \%$ [1]. In the chemical industry, salt is a raw material and supporting material. For humans, salt is a food seasoning. Simply put, what is needed by industry in salt is minerals (Sodium Chloride), while the salt needed for seasoning is its salty taste [3]. The low quality of local salt produced by Indonesian salt farmers makes it difficult for them to compete with imported salt. The government stated that this was due to the limited number of farmers' farmlands which affected the sedimentation and purification processes [4]. Salt deposition process requires $90 \%$ of the total area of ponds. Whereas salt crystallization only requires $10 \%$ of the entire farm area. The lack of pond area also affects the level of purity or impurity of local salt. Local salts only account for $95 \%$ of the impurity, while the salt impurity required by the Chlor Alkali Plant (CAP) industry must reach $99 \%$. [5]. Salt production of Indonesian local farmer is currently only able to meet the needs of consumption salt because the quality of Indonesian salt only contains about $94 \%$ to $95 \% \mathrm{NaCl}$ [6]. Therefore, local salt is difficult to be absorbed by with salt-based products industry because its purity level does not meet the industrial standards. As a result, imports of industrial salt will increase because local salt cannot meet the industry needs [4].

In East Java, there are several salt production centers, including Sampang, Sumenep, Pamekasan, Gresik, Pasuruan, Sidoarjo, Probolinggo, Tuban, Lamongan and Surabaya [7]. However, due to the relatively low quality of local production salt, the salt production is only able to meet the needs of consumption salt and is still unable to meet the needs of industrial salt. Data collected from the Coordinating Ministry for Economic Affairs about the needs, imports and production of national salt shows that salt imports number are higher than national salt production number, as shown at Figure 1.

A report from the Coordinating Ministry for Economic Affairs states that the total national salt production in 2019 is expected to decrease by $14.4 \%$, or to around 2.3 million tons. In fact, salt production in $2017-2018$ increased by $561.3 \%$ and $144.7 \%$ to 1.1 million tons and 2.7 million tons, respectively. The biggest decline in national salt production occurred in 2016, which reached 93.23\%, from 2.5 million tons to 168 thousand tons. Meanwhile, the need for salt every year always increases along with population growth and industrial growth. In 2019, the national salt demand is estimated to increase by $5.98 \%$, which is 4.2 million tons. Therefore, the government allocates salt imports in 2019 to increase by $0.2 \%$ to 2.72 million tons, compared to 2018 which amounted to 2.71 million tons. The highest increase in salt imports occurred in 2017, which was $19 \%$, with an increase from 2.1 million tons to 2.6 million tons [8].

Based on data from the Central Bureau of Statistics (BPS) regarding the volume and cost of salt imports from 2014 to May 2019, the highest volume of salt imports since 2014 occurred in 2018 which reached 2.8 million tons, up $11.2 \%$ from the previous year which amounted to 2.6 million tons. Salt imports only decreased in 2015, which is $-17.8 \%$ from 2.3 million tons to 1.9 million tons. Until May 2019, the salt imports have reached 1 million tons [9].

The cost of salt imports in 2018 was US \$ 90.7 million. This amount increased by $8.4 \%$ from the previous year which 
The $6^{\text {th }}$ International Seminar on Science and Technology (ISST) 2020

July $25^{\text {th }} 2020$, Institut Teknologi Sepuluh Nopember, Surabaya, Indonesia

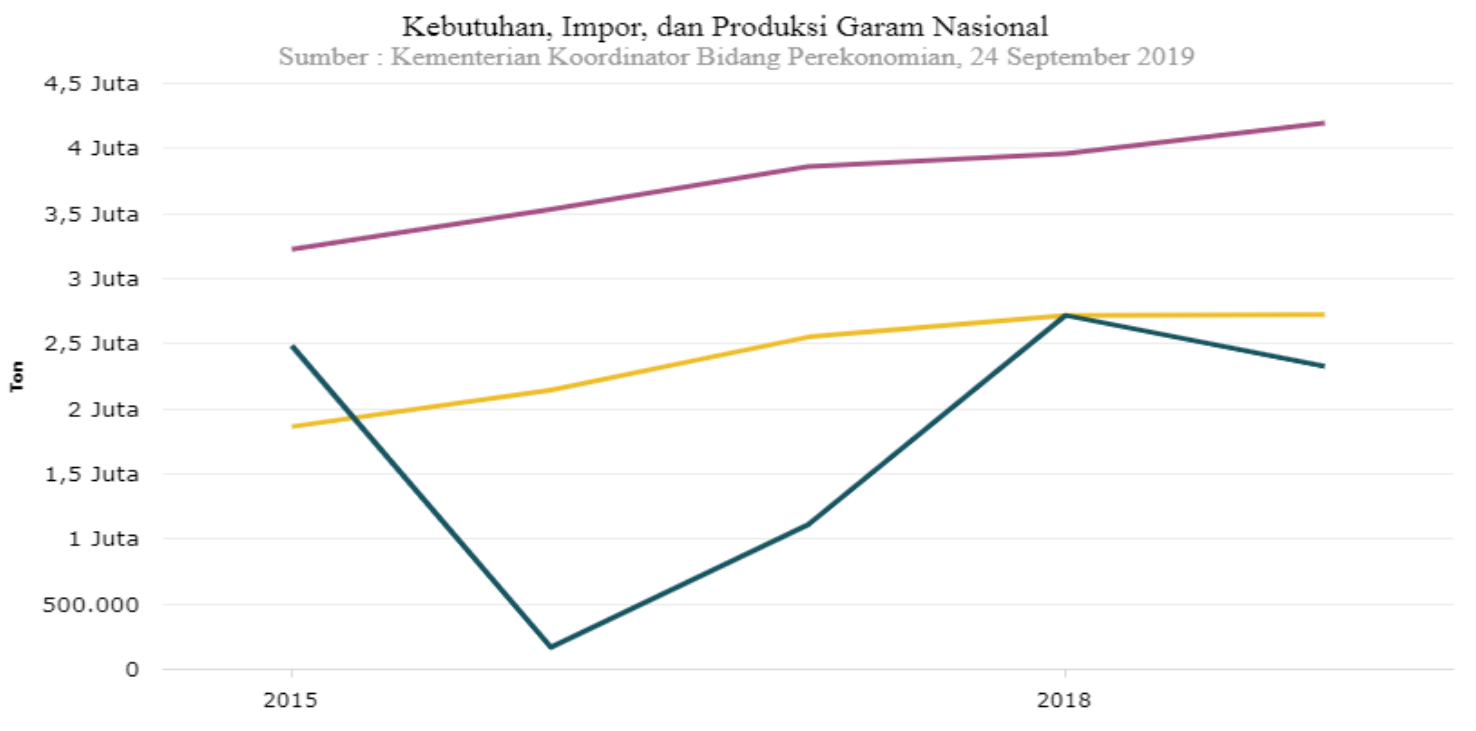

Dkatadata

Wdataboks

Figure 1. The Needs, the Import, and the Production of National Salt

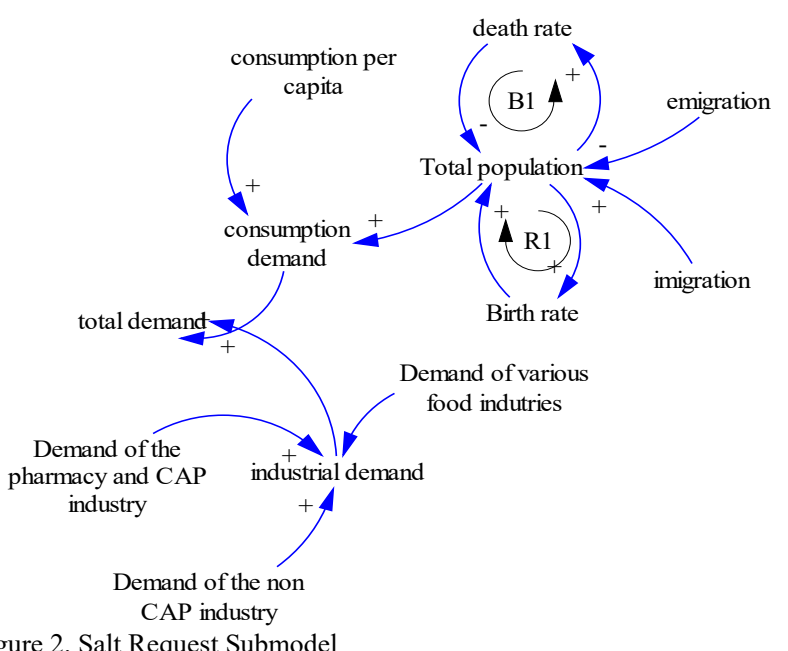

Figure 2. Salt Request Submodel

was US \$ 83.6 million. The cost of salt imports has also once dropped to more than $23.5 \%$ in 2015 amounting to US \$ 79.8 million, from the previous year which reached US $\$ 104.3$ million. If these conditions continue, the local salt prices will continue to plummet, causing Indonesian salt farmers to continue to suffer losses.

From these characteristics and problems, this study uses system dynamics modeling to understand the real condition of salt cultivation system and develop a system to improve the quality of salt produced by Indonesian farmers. The results of this study are salt cultivation models based on the real conditions being modeled. This paper is organized as follows. Section 1 explains the introduction. Section 2 explains the method. Section 3 presents the results. Section 4 explains the conclusions.

\section{METHOD}

This research was conducted using dynamic system modeling because it can describe the components involved in

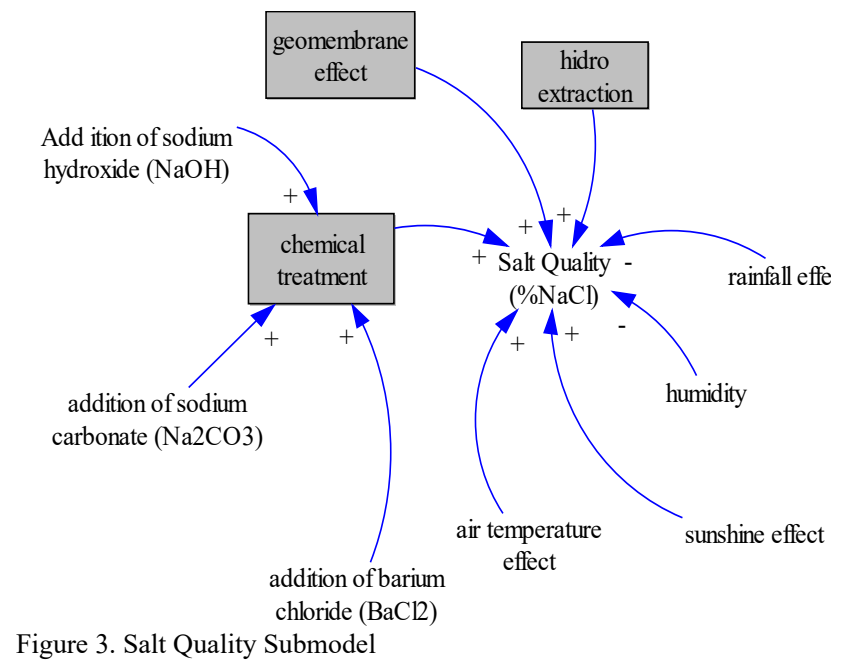

the system and how these components interact so that the behavior or patterns of the system can be understood [10]. The resulting model will then be analyzed and engineered with the aim of increasing effectiveness or making improvements to the system as needed. The dynamic system simulation approach is considered suitable, because it is based on feedback in one part of the system that affects other parts [11].

\section{A. Dynamic System}

System Dynamics is a method for analyzing and designing policies for complex systems. It can be used as an approach for modeling and simulating complex systems. Sterman described system dynamics as an aid to learn and to understand complex systems [12]. He emphasized how the process of system dynamics modeling consists of tools for obtaining mental models of systems, procedures for creating formal models based on mental models, computer simulations of formal models, and application of simulation findings to improve system understanding. 
The $6^{\text {th }}$ International Seminar on Science and Technology (ISST) 2020

July $25^{\text {th }} 2020$, Institut Teknologi Sepuluh Nopember, Surabaya, Indonesia

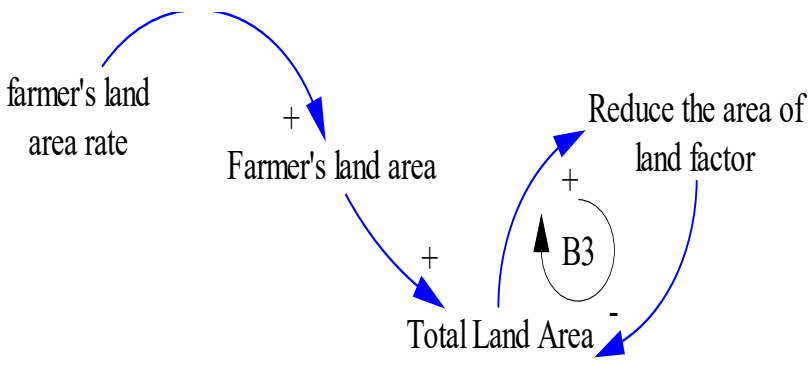

Figure 4. Land Area Submodel.

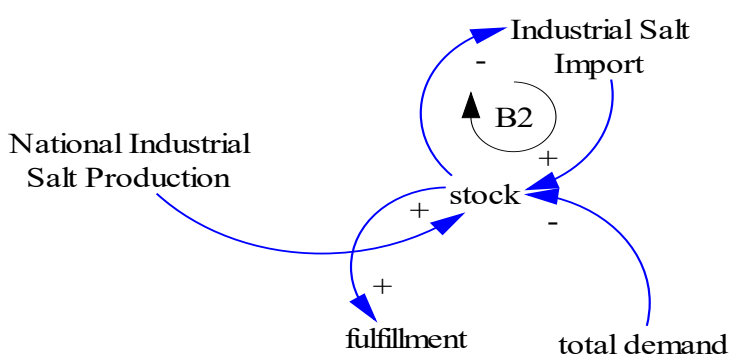

Figure 5. Industrial Salt Import Submodel

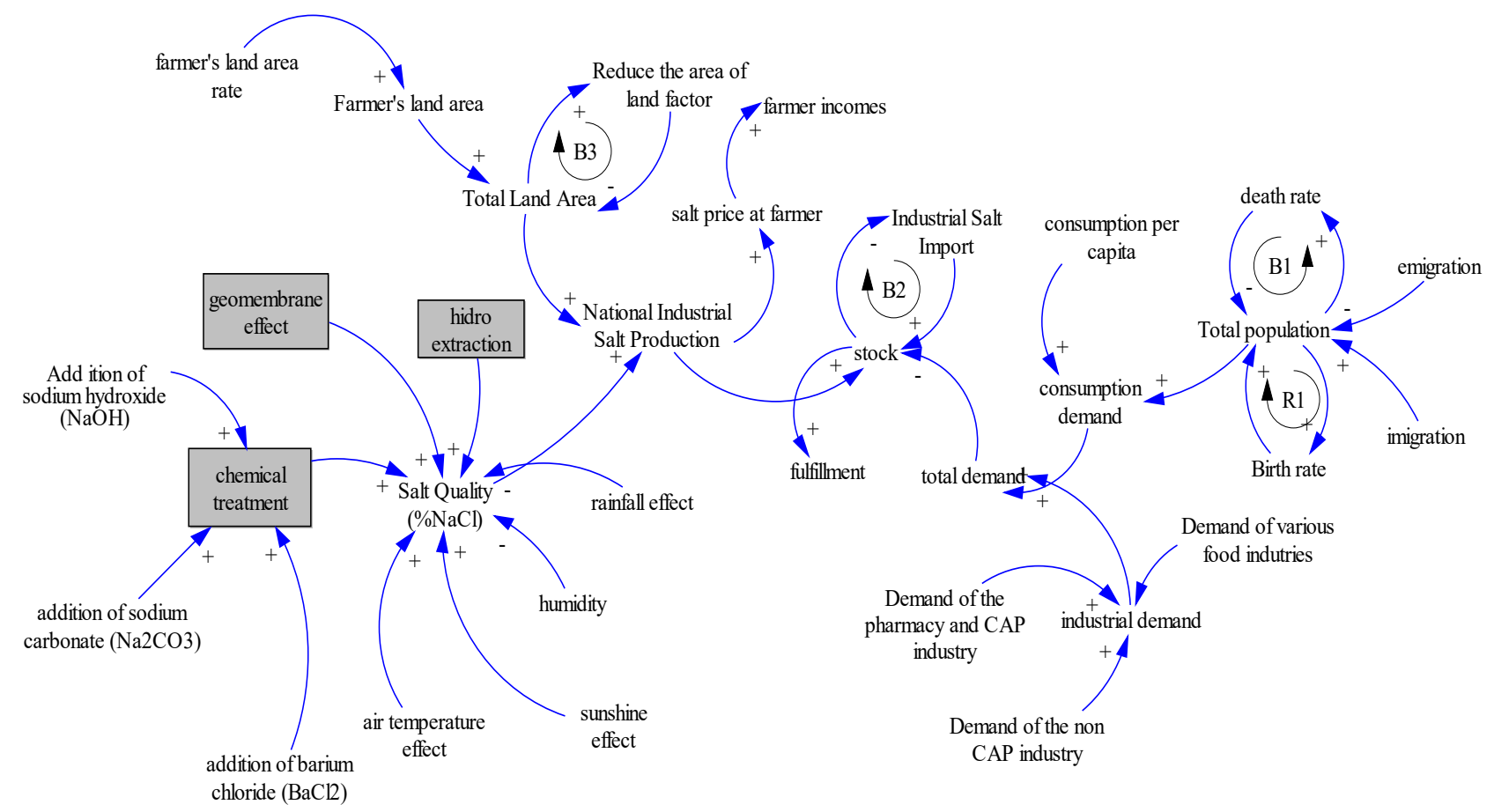

Figure 6. Causal Loop Diagram of Salt Cultivation

According to Barlas (1996), the development of system dynamics models is carried out in several stages including: (1) problems identification, (2) concept model construction, (3) formal model development, (4) model analysis and validation, (5) policy analysis and design [13].

\section{B. Modeling}

Modeling is made to describe the components involved in a system and how these components interact so that the behavior or pattern of the system can be understood. The resulting model will then be analyzed and engineered with the aim of increasing effectiveness or making improvements to the system as needed. The first thing to do when making a modeling is to determine the purpose of the modeling. The modeling cycle according to Sterman (2000) consist of [12]:

1. Problem Articulation, the identification of problems, goals, and limitations to be solved.

2. Dynamic Hypothesis, making initial hypotheses based on the identification of problems from the previous phase, it can be in the form of diagrams.

3. Formulation, the formulation of the model based on diagrams formed in the previous phase, it is generally in the form of mathematical equations.

4. Testing, testing with various policy scenarios.
5. Policy formulation and evaluation, taking or utilizing the policy from trials in the previous phase as needed, and conducting evaluations.

\section{Simulation}

Simulation is an efficient tool for conducting engineering experiments on an ongoing system by using computer assistance to make policies or decisions that suit your needs. Engineering systems that are carried out in real are costly and time consuming, it also difficult to ensure that the engineering carried out is the best way and fit the needs.

According to Law and Kelton (1992), simulation is a process of duplication of techniques that occur in real systems using computer assistance based on certain assumptions, so that it can be understood scientifically [14]. The simulations are used by computers to be studied against the system in numerical methods, trials with data are carried out for statistical estimation to get a picture of the characteristics of the system. The approach to using simulation starts with modeling the system that you want to engineer.

\section{Model Verification and Validation}

Validation and verification of models that have been made aim to ensure that the model created is almost the same as the 
The $6^{\text {th }}$ International Seminar on Science and Technology (ISST) 2020

July $25^{\text {th }} 2020$, Institut Teknologi Sepuluh Nopember, Surabaya, Indonesia

Table 1.

Salt Cultivation Boundary Adequacy

\begin{tabular}{|c|c|c|c|c|}
\hline Type & Name & Unit & Reference & Formula \\
\hline \multirow{8}{*}{ Internal } & Geomembran effect & Sheet & [15] & \\
\hline & Chemical Treatment & Gram & & \\
\hline & Hidro extraction & & & \\
\hline & Salt Quality & Percent & [16] & Salt Quality $=$ (air temperarure + sunshine effect - Rainfall effect - humidity \\
\hline & Total land area & $\mathrm{Ha}$ & [17] & $\begin{array}{l}\text { Total land area }=(\text { Land area farmer }+ \text { Land area government }+ \text { Land area } \\
\text { private sector })- \text { Reduce plant area factor }\end{array}$ \\
\hline & $\begin{array}{l}\text { National } \\
\text { Production }\end{array}$ & Ton & [18] & Industrial Salt Production $=$ Total land area * Amount of Salt Quality \\
\hline & Fulfillment & Ton & [19] & Fulfillment $=$ Industrial Salt production - Total demand \\
\hline & Industrial Salt Import & Ton & & \\
\hline \multirow{18}{*}{ External } & Air Temperature & ${ }^{\circ} \mathrm{C}$ & [16] & \\
\hline & Sunshine & & [16] & \\
\hline & Rainfall & Mm/year & [16] & \\
\hline & Humidity & $\%$ & [16] & \\
\hline & Total Demand & Tons & [17] & Total Demand $=($ Industrial Consumption + total population $)-$ Fulfillment \\
\hline & $\begin{array}{l}\text { Consumption of the alkaline } \\
\text { chlorine industry }\end{array}$ & Tons & [20] & \\
\hline & $\begin{array}{l}\text { Consumption of the } \\
\text { pharmaceutical industry }\end{array}$ & Tons & [20] & \\
\hline & $\begin{array}{l}\text { Consumption of the non CAP } \\
\text { industry }\end{array}$ & Tons & [20] & \\
\hline & $\begin{array}{l}\text { Consumption of various food } \\
\text { industries }\end{array}$ & Tons & [20] & \\
\hline & Industrial Consumption & tons & [20] & $\begin{array}{l}\text { Industrial Consumption }=\text { Consumption of the CAP industry }+ \text { Consumption } \\
\text { of the pharmaceutical industry + Consumption of the non CAP industry }+ \\
\text { Consumption of various food industries }\end{array}$ \\
\hline & Birth rate & People/year & [21] & \\
\hline & Death rate & People/year & [21] & \\
\hline & Immigration rate & People/year & & \\
\hline & Emmigration rate & People/year & & \\
\hline & Total Population & People & [17] & $\begin{array}{l}\mathrm{Pt}=\mathrm{Po}+(\mathrm{L}-\mathrm{M})+(\mathrm{I}-\mathrm{E}) \\
\mathrm{Keterangan}: \\
\mathrm{Pt}=\text { population at the end of the year } \\
\mathrm{Po}=\text { population at the beginning of the year } \\
\mathrm{L}=\text { number of births } \\
\mathrm{M}=\text { number of deaths } \\
\mathrm{I}=\text { number of immigration (the number of people entering the area) } \\
\mathrm{E}=\text { amount of emigration (the number of people leaving the area) }\end{array}$ \\
\hline & Farmer's Land area & $\mathrm{Ha}$ & [19] & \\
\hline & Farmer's Land area rate & Ha/year & [19] & \\
\hline & Reduce the area land & $\mathrm{Ha}$ & [19] & \\
\hline
\end{tabular}

real conditions or is able to represent the system. According to Barlas (1996), model validation and verification can be done with two approaches, namely [13]:

1) Average Comparison Test (Mean comparasion)

This test is carried out by using the following formula:

$E 1=\left|\frac{S-A}{A}\right|$

Where:

$\mathrm{S}=$ the simulation results average value

$\mathrm{A}=$ the data average value
The model is said to be valid if the value of $\mathrm{E} 1 \leq 5 \%$.

2) Amplitude Variation Comparison Test (\% error variance)

This test is carried out by using the following formula:

$E 2=\left|\frac{S s-s a}{s a}\right|$

Where:

Ss $=$ Standard deviation of the model

$\mathrm{Sa}=$ Standard deviation of the data

The model is said to be valid if the value of E2 $\leq 30 \%$. 
The $6^{\text {th }}$ International Seminar on Science and Technology (ISST) 2020

July $25^{\text {th }} 2020$, Institut Teknologi Sepuluh Nopember, Surabaya, Indonesia

\section{RESULT AND DISCUSSION}

This section presents the results of internal and external factors that affect salt cultivation based on literature studies that have been done before, then the basic pattern of the system and the relationship of each variable in the causal diagram is presented. The results of literature studies from books, as well as government sites and private sites such as BPS (Central Bureau of Statistics), the Ministry of Industry, PT. Garam, articles in relevant journals or previous research, as well as mass media websites, the internal and external factors that affect the quality of salt in Indonesia are obtained. The following is the results projection of this study:

\section{A. Boundary Adequacy}

Internal and external factors, both significant and auxiliary variables that influence each other in the system dynamics modeling for salt cultivation are listed in Table 1.

\section{B. Basic Pattern of the System}

The basic pattern of the system helps in making detailed submodels in a causal diagram of salt cultivation. In this case, there are 4 sub-models that must be specified, including: (1) salt demand, (2) salt quality, (3) land area, and (4) industrial salt imports.

\section{1) Salt Demand Sub Model}

Figure 2 presents a generic structure of the salt demand problem, which illustrates a causal diagram of salt demand to meet consumption needs and the needs of various industries. One of the variables that influences the demand for salt consumption is population. The population itself is affected by several factors such as the number of immigrations, the number of emigrations, the birth rate (R1) and the death rate (B1). The more the consumption per capita and population, the greater the demand for consumption salt, so it shows a positive polarity $(+)$. While the variables that affect the demand for industrial salt are the demand for pharmacy and $\mathrm{CAP}$ industries, the demand for non-CAP industries, and the demand for various food industries.

2) Salt Quality Sub Model

Figure 3 presents a generic structure of salt quality problems. There are several internal and external factors that affect the quality of salt. The causal loop diagram of salt quality sub-model consists of: (1) The use of geomembrane. Geomembrane has a considerable effect on salt quality, so using it is one of the variables that can be used as a scenario to improve salt quality. Geomembrane is a layer of HDPE sheets that are spread on salt field and functions as a waterproof barrier between the soil and other parts, so that the salt formed has better quality because it does not mix with dirt / other objects. (2) The addition of chemicals, such as sodium hydroxide $(\mathrm{NaOH})$, sodium carbonate $(\mathrm{Na} 2 \mathrm{CO} 3)$ and barium chloride $(\mathrm{BaCl} 2)$ to reduce pollutant ions (calcium $(\mathrm{Ca} 2+)$, Magnesium $(\mathrm{Mg} 2+)$, and sulfate $(\mathrm{SO} 42-))$. The addition of these chemicals can also be used as a scenario to improve the quality of salt. (3) Hydro extraction, which is the process of extracting or separating insoluble components such as dust, soil, and sand as well as soluble substances such as magnesium $(\mathrm{Mg})$, calcium $(\mathrm{Ca})$, and sulfate (SO4). Hydro extraction can also be used as a scenario to improve the quality of salt. (4) Air Temperature, the higher the air temperature, the faster the evaporation of sea water will be.
(5) Solar radiation, like air temperature, the more the sunlight (not cloudy), the faster the evaporation of sea water will be. (6) Rainfall. (7) Humidity. Both rainfall and humidity have a negative effect on the evaporation of sea water. The higher the rainfall or humidity, the longer the process of evaporation of sea water will be, and it will affect the quality of salt to be produced

\section{3) Land Area Sub Model}

Figure 4 presents the generic structure of land area in salt cultivation. The salt cultivation area is affected by the land area of salt farmer and the land conversion. Land conversion will reduce the amount of land available for salt cultivation. The larger the area of salt cultivation, the greater the land conversion intensity (B3). Conversion of salt cultivation areas are due to land use changes into settlements, tourist attractions, and other public facilities.

\section{4) Industrial Salt Import Sub Model}

Figure 5 presents the generic structure of total industrial salt imports. Industrial salt imports are affected by industrial salt stocks. The lower the industrial salt stock, the higher the number of industrial salt imports, conversely, the higher the industrial salt stock, the lower the number of industrial salt imports.

At last, Figure 6 presents the overall causal diagram of salt cultivation including salt demand, salt quality, land area, and industrial salt imports.

\section{CONCLUSSION}

Based on the results of analysis and discussion carried out in this study, it can be concluded:

1. Salt cultivation system is a system with complex problems involving various variables in it that are interrelated. The analysis results of the salt cultivation system produced some important information regarding the internal and external variables affecting it.

2. Conceptual models (causal loop diagrams) can be used to illustrate the interrelationship between variables and behavior patterns that occur in salt cultivation systems, especially in improving the quality of salt.

3. The conceptual model (causal loop diagram) that is built can represent the current condition and can be used as a diagnostic tool to provide a deeper understanding of the problems that arise, so it can be used as a basis for policy / scenario making.

4. The conceptual model (causal loop diagram) that is built can be used by the government and stakeholders to support decision making or to support development of strategies and policies related to salt cultivation systems in order to achieve industrial salt self-sufficiency.

5. From the resulting causal diagram, further research can develop several new scenarios in order to reduce the cost of salt production and increase the income of salt farmers.

\section{ACKNOWLEDGEMENTS}

This research was supported by the Department of Information Systems, Institut Teknologi Sepuluh Nopember (ITS) Surabaya. We would like to thank Erma Suryani, ST, 
The $6^{\text {th }}$ International Seminar on Science and Technology (ISST) 2020

July $25^{\text {th }} 2020$, Institut Teknologi Sepuluh Nopember, Surabaya, Indonesia

MT, Ph.D. which takes an important part in the research process.

\section{REFERENCES}

[1] N. T. S. P. Jaya and R. H. W, "Produksi garam dan bittern di tambak garam," Jurnal Kelautan Tropis, vol. 19, pp. 43-47, 2016.

[2] Rusiyanto, E. Soesilowati and Jumaeri, "Penguatan industri garam nasional melalui perbaikan teknologi budidaya dan diversifikasi produk," Jurnal Sain dan Teknologi, vol. 11, no. 2, pp. 1-14, 2013

[3] Kemenperin, "Impor Garam untuk Penuhi Bahan Baku Industri," 2018. [Online]. Available: https://kemenperin.go.id/artikel/18974/Impor-Garam-untukPenuhi-Bahan-Baku-Industri. [Accessed 9 June 2020].

[4] R. Alika, "Kemenperin Sebut Kualitas Garam Lokal Rendah Karena Terbatasnya Lahan," 2019. [Online]. Available: https://katadata.co.id/berita/2019/08/07/kemenperin-sebutkualitas-garam-lokal-rendah-karena-terbatasnya-lahan. [Accessed 0906 2020].

[5] S. Asillah, "Kehadiran Komprador dalam Garam Impor," 2020. [Online]. Available: https://www.muslimahvoice.com/2020/01/kehadiran-kompradordalam-garam-impor.html. [Accessed 9 June 2020].

[6] Z. Salim and E. Munadi, "Info Komoditi Garam," Al Mawardi Prima, Jakarta, 2016.

[7] G. D. Putra, "10 Daerah Produsen Garam Indonesia," 2018. [Online]. Available: http://indonesiabaik.id/infografis/10-daerahprodusen-garam-indonesia. [Accessed 9 June 2020].

[8] D. H. Jayani, "Impor Garam Lebih Tinggi daripada Produksi Garam Nasional," 2019. [Online]. Available: https://databoks.katadata.co.id/datapublish/2019/09/24/imporgaram-lebih-tinggi-daripada-produksi-garam-nasional. [Accessed 19 April 2020].

[9] D. H. Jayani, "Volume dan Nilai Impor Garam 2014-Mei 2019," 2019. [Online]. Available: https://ataboks.katadata.co.id/datapublish/2019/08/23/berapavolume-dan-nilai-impor-garam-indonesia. [Accessed 9 June 2020].
[10] J. D. Sterman, Business Dynamics: System Thinking and Modeling for a Complex World, McGraw-Hill/Irwin: Jeffrey J. Shelstad, 2000.

[11] A. Ford, Modeling The Environment: An Introduction To System Dynamics Models Of Environmental Systems, Island Press, 1999.

[12] J. D. Sterman, Business Dynamics: Systems Thinking and Modeling for a Complex World, Boston: McGraw-Hill Education, 2000 .

[13] Y. Barlas, "Formal aspects of model validity and validation in system dynamics," System Dynamics Review, vol. 12, no. 3, pp. 183-210, 1996.

[14] A. M. Law and w. D. Kelton, Simulation Modelling and Analysis, 2nd ed., New York: McGraw·HiII, InC, 1992.

[15] Z. A. Abdullah and A. Susandini, "Media produksi (Geomembrane) dapat meningkatkan kualitas dan harga jual garam," Eco-Entrepreneurship, vol. 3, no. 2, pp. 21-36, 2018.

[16] G. W. R. Kemala, "Analisis Faktor-faktor yang Memengaruhi Impor Garam Indonesia (Dari Negara Mitra Dagang Australia, India, Selandia Baru, dan Cina)," Bogor Agricultural University, Bogor, 2013.

[17] P. A. Hariwibowo, R. Anindita and Suhartini, "The evaluation of Indonesia import policies of garlic," Greener Journal of Business and Management Studies, vol. 5, no. 1, pp. 16-30, 2015.

[18] A. B. Putra and B. Nugroho, "Peramalan produksi kedelai menggunakan pendekatan sistem dinamik," Jurnal Sistem Informasi dan Bisnis Cerdas (SIBC), vol. 9, no. 1, pp. 57-70, 2016

[19] A. B. Putra, S. Mukaromah and P. M. Kusumantara, "Analysis of the maize systems to increase production with a dynamic system approach," Proceedings of the International Conference on Science and Technology (ICST 2018), Surabaya, 2018.

[20] Kemenperin, "Kementerian Perindustrian Republik Indonesia," 2019. [Online]. Available: https://kemenperin.go.id/artikel/20911/Kemenperin-FasilitasiPenyerapan-Garam-Lokal-Sebanyak-1,1-Juta-Ton. [Accessed 2 March 2020].

[21] A. B. Putra, S. Mukaromah and N. C. Wibowo, "Analysis of soybean production to achieve soybean self-sufficiency using system dynamics approach," The 2nd International Joint Conference on Science and technology (IJCST) 2017, Surabaya, 2017. 